\title{
Linguistic Relativity, Cultural Relativity, and Foreign Language Teaching
}

\author{
A. Effendi Kadarisman \\ State University of Malang
}

\begin{abstract}
Every language is assumed to be unique, structurally and culturally. Taking this neo-Bloomfieldian assumption at the outset, this paper first points out the inadequacy of sentence grammars for foreign language teaching. Toward this end, the paper further argues for the necessity of understanding linguistic and cultural relativity. Linguistic relativity, or better known as the Sapir-Whorf hypothesis, suggests that the way we perceive and categorize reality is partly determined by the language we speak; and cultural relativity implies that verbalization of concepts in a particular language is often culturally conditioned. As related to the field of foreign language teaching, relativity across languages and cultures presupposes contrastive analysis in a very broad sense. Thus pointing out differences in language structures and cultural conventions should lead students to better acquisition of linguistic and cultural sensitivity.
\end{abstract}

Key words: linguistic relativity, cultural relativity, Sapir-Worf hypothesis, foreign language teaching

\section{"ALL GRAMMARS LEAK"}

The statement "All grammars leak" is a quotation from Edward Sapir's Language (p. 38), first published in 1921; and since then its predictive power has been revealing. This section gives a brief overview of grammars and points out how they leak. My approach in this section is both analytical and historical, and the argument in this paper swings back and forth between applied and theoretical linguistics. Since modern linguistics as the 
Saussurean legacy is best defined as structuralism, a linguistic investigation of culture is predominantly structural, methodologically as well as technically.

Let us start with the Audiolingual Method (ALM). It was, in my opinion, a perfect illustrative example of applied linguistics in the sense that structuralist scholars in the United States directly applied linguistic principles in the field of foreign language teaching. The reader may recal the "five slogans of the day," outlined during the early 1960s by one ALM proponent William Moulton (see Rivers 1981: 41-3):

1. Language is speech, not writing

2. A language is a set of habits.

3. Teach the language and not about the language.

4. A language is what its native speakers say, not what someone thinks they ought to say.

5. Languages are different.

Among these five slogans, four of them (i.e., nos. 1, 2, 4, 5) are fundamental principles in American Structural Linguistics; and only slogan no. 3 is directly concerned with language teaching. Thus the ALM was wholly confined within the American Structuralism. Today, we often mention the ALM with some regret, remembering that the excessive drilling and pattern practice we did during the 1970s and early 1980s did not really work out beyond the phonology of English. Then we started questioning whether language is truly a set of habits. After all, Chomsky (1965: 6) says that human language is fundamentally creative; and he rejects the mechanistic stimulus-response-reinforcement chain believed then to be the mental process of language acquisition.

In the early conception of Generative Grammar during the 1960s, Chomsky pointed out that grammatical descriptions resulting from the linguistic enterprise in American Structuralism lacked descriptive adequacy, that is, a complete and accurate description of a language under investigation. In other words, the "grammar" in American Structuralism leaked. When the fundamental linguistic assumptions of the ALM leaked and eventually collapsed, the ALM consequently fell apart.
The rise of Generative Grammar with fascinating terms (such as competence and performance, deep structure and surface structure) made EFL scholars hopeful that the new school of linguistics would bring some enlightenment to their field. In 1966 Chomsky was invited to the Northeast Language Teachers' Association, with the hope that he would help set up a better teaching methodology. But it turned out to be a big disappointment. In a seven-page-long paper documented in the proceeding, Chomsky presented a brief outline of Generative Grammar: "the 'creative' aspect of language use, the abstractness of linguistic representation; the universality of underlying linguistic structure; [and] the role of intrinsic organization in cognitive processes" (p. 46). But he was skeptical about the significance of linguistic insights for language teaching, saying, "I would like to stress that the implications of these [linguistic] ideas for language teaching are far from clear to me" (p. 49).

Indeed, direct application of Chomskyan linguistic theory in the field of TEFL would not yield much benefit, because for Chomsky language is a mirror of the mind (1968: $\mathrm{x}$ ). That is, language is a mental fact and a matter of individual psychology. This is quite contrary to the fact that in the EFL classroom language is taught as a means of verbal communication. In this context, Krashen's (1982) Monitor Theory may be considered to be the best interpretation of Chomskyan theory for the benefit of TESL/TEFL. Krashen believes that the language acquisition device (LAD)-the term was first introduced by Chomsky in Aspects (1965)-does the processing of comprehensible input into the so-called acquired competence. His acquisition-learning hypothesis in the Monitor Theory is meant to prove that "acquisition" and "learning" in L2 are distinct from each other; the former is the L2 competence resulting from the LAD being exposed to natural language use, whereas the latter is the result of formal teaching and learning. While the validity of the acquisition-learning distinction is debatable, it is obvious that Krashen's monitor theory is strongly mentalistic in nature, just as Chomsky's linguistic theory is also strongly mentalistic. Both theories try to account for the nature of mental grammar or linguistic competence-L2 competence and $\mathrm{L} 1$ competence respectively.

Grammar is not something we learn, but it is the LAD naturally growing into competence as a result of its exposure to the surrounding language input. In the latest development of the generative enterprise, the LAD is better known as Universal Grammar (UG), namely, "the set of 
linguistic principles we are endowed with at birth in virtue of being human" (Smith 1999: 42). Like the older terms competence and performance, UG is equally or even more strongly appealing, not only to theoretical linguists but also to some applied linguists. Lydia White's Universal Grammar and Second Language Acquisition is a good example of how the present generative theory is used to describe and explain the nature of acquiring grammatical items among L2 learners. The underlying assumption is that $\mathrm{UG}$, which is believed to determine $\mathrm{L} 1$ acquisition, is still there in the part of L2 learners and partly determines the course of L2 development.

Words of caveat: don't get too fascinated with UG. It deals mainly with syntax. Thus, as related to TEFL, the problem with UG is that it is only partly, and not wholly universal. UG is indeed a glorious name, but it will never bring TEFL to glory. For the practical purposes of TEFL (but not the theoretical explanation in SLA), UG not only leaks but is almost totally inadequate.

Just as EFL scholars are not happy with generative theory, theoretical linguists-especially those concerned with the study of language use or language in context-are no less critical in their attitudes. It is no doubt that the Chomskyan revolution has made unprecedented, remarkable progress in syntax. Yet, interestingly, as noted by Lavandera (1988:1), it has also indirectly brought about proliferation in the study of language use.

It does not seem far-fetched to hold Chomsky indirectly responsible for the accelerated development in sociolinguistics and ethnolinguistics at the end of the 1960s and for the emphasis laid upon pragmatics and discourse analysis in the mid 1970s. Paradoxical as it may seem, his revival of the Saussurean langue-parole dichotomy (under the name "competence" and "performance"), and even more important, his assertion of the autonomy of syntax, sparked renewed interest in the study of language in its sociocultural context.

The theoretical movement from context-free linguistics to the study of language in its interpersonal and sociocultural context is on a par with the pedagogical movement from structural to communicative approach. In fact the term "communicative competence," becoming well-known later through the adoption of Communicative Approach in TEFL, was first proposed by the American sociolinguist Dell Hymes (1972), as his strong reaction against Chomsky's "linguistic competence." Linguistic competence, Hymes argues, is nothing but grammatical competence which, together with discourse and sociolinguistic competence, constitutes communicative competence. This is in accord with the fact that language is a sociocultural entity, first and primarily designed as a means of communication.

Referring to "ethnolinguistics" (i.e., the study of language variation as determined by the cultural values of a given speech community) in the quotation above and to Edward Sapir, who said that "All grammars leak," it seems justifiable to me to conclude this section by outlining the well-known Sapir-Whorf hypothesis. According to this hypothesis, the way we perceive the world is partly determined by the language we speak. Or more clearly, our native language partly determines our thought pattern. This is what is called "linguistic relativity." It often goes hand in hand with "cultural relativity," That is, culture-specific values are often revealed by means of language-specific expressions. Both linguistic relativity and cultural relativity constitute major topics in the following section.

\section{LANGUAGE THE CULTURAL MIRROR}

The title of this section is a slight modification of Chaika's book (1982), Language the Social Mirror. The metaphoric use of "mirror" here suggests the reflection of two things: (a) language, or more precisely languagespecific structures, as reflected in language-specific thought patterns, and (b) culture-specific values as reflected in language-specific expressions. The "mirror" metaphor here leads to formulating a 'neo-Bloomfieldian' assumption: "Every language is unique, structurally and culturally." Below I will discuss the two aspects of reflection above under the headings: (a) linguistic relativity and thought patterns, and (b) cultural relativity and language-specific expressions. It should be noted in passing, however, that the distinction between the two topics is not always clear-cut, and therefore there may be some overlap covering parts of both domains.

\section{Linguistic Relativity and Thought Patterns}

The notion that every language is structurally unique is best captured by Jakobson (1959: 142), who states, "The true difference between languages is not in what may or may not be expressed but in what must or must not be conveyed." This statement is especially true as related to the cover term "grammaticization," meaning realizing concepts as grammatical markers 
(Slobin 1996). The linguistic concept such as "plural" and the logical concept such as "space" and "time" are explicitly grammaticized in English, but not in Indonesian. Referring to unique structures in English, the reader is certainly familiar with realizing the concepts "plural" and "time" as "plural markers" and "tense." In the present context, owing to space limitation, only the grammaticization of "space" is presented here as an illustrative example. Spatial dimension is commonly expressed by means of prepositions or particles. Speaking to someone up on a tree or down in a well, an Indonesian would ask,

(1) Mengapa kamu di situ?

In English, however, the spatial dimension must be taken into account, and hence the appropriate question would be

(2) What are you doing up there? and

(3) What are you doing down there?

Notice the use of the particles "up" and "down" in both examples showing the spatial dimension. In effect, the deletion of either particle in (2) and (3) by Indonesian learners of English would not result in ungrammaticality, but it would make both sentences sound less English.

In his experiment "from pictures to narrative stories," Slobin (1996) showed a picture (of a bird going out of a hole in a tree flying down) to English and Spanish speakers. A speaker of English describes the picture as follows:

(4) The bird flew down from out of the hole in a tree.

On the other hand, the description given by a Spanish speaker has the following English equivalent:

(5) The bird exited of the hole of the tree flying toward below.

Notice that the four prepositions "down from out of" occurring in a row in the English sentence are gone in the Spanish rendering. An Indonesian translation of the sentence will be much closer to the Spanish than English version.

(6) Burung itu keluar dari lubang pohon (dan) terbang merendah.

Idiomatic expressions in English such as come in, go out, get on, get off, a mile away, up and down the hill, bottom-up or top-down approach, off Broadway, and off off Broadway - all of these indicate that spatial dimension gets explicitly grammaticized in English. In sum, spatial dimension is there as reality in the outside world available for observation by speakers of
English, Spanish, and Indonesian; and yet it is grammaticized only in English.

English is also different from Indonesian in terms of syntactic patterning. Let's take grammatical subject as an example. English is a subject-prominent language, meaning that almost every sentence requires a subject. On the contrary, in Indonesian, particularly in spoken discourse, a subject may be deleted so long as it is recoverable from the context.

(7) When did you arrive?

(8) Kapan datang?

The obligatory subject you in (7) may optionally be deleted in (8), and its reference is made possible by the conversational context. For this reason, the dummy (meaningless) subject there or the expletive (meaningless) subject it must be there in an English sentence simply to fill up the subjectprominence requirement.

(9) It's very easy to do this exercise.

(10) There is a nice painting in the living room.

Indonesian has no "meaningless" subjects, and therefore it in (9) and there in (10) have zero equivalents.

(11) Mudah sekali mengerjakan latihan ini.

(12) Ada lukisan bagus di ruang tamu.

Additional examples can be seen in parts of the poem "Pelarian," by Chairil Anwar, given in Table 1 along with its English translation, "Fugitive," by Burton Raffel (1993: 14-5), as a comparison showing strong contrast in subject prominence within two languages. Poetry translation means carrying over the poetic meaning and form, if possible, from the target language to the source language. In the present context, the source language is Indonesian and the target language is English. With respect to language form, the translation has to obey the grammatical rules inherent in the target language (English), one of them being the rule of subject prominence. 
Table 1. The poem "Pelarian" and its English translation "Fugitive"

\begin{tabular}{l|l}
\multicolumn{1}{c|}{ "Pelarian" } & \multicolumn{1}{|c}{ "Fugitive" } \\
\hline $\begin{array}{l}\text { Tak tertahan lagi } \\
\text { remang miang sengketa di sini }\end{array}$ & $\begin{array}{l}\text { Enough! He can't stand } \\
\text { this fierce, yearning fight! }\end{array}$ \\
$\begin{array}{l}\text { Dalam lari } \\
\text { Dihempaskannya pintu keras tak } \\
\text { berhingga }\end{array}$ & $\begin{array}{l}\text { He runs out, } \\
\text { slamming the door behind him }\end{array}$ \\
$\begin{array}{l}\text { Hancur-luluh sepi seketika } \\
\text { Dan paduan dua jiwa }\end{array}$ & Silence (and the oneness of two hearts) \\
\end{tabular}

Notice that in the first couplet in Indonesian, the sentence has neither grammatical nor logical subject; but in its English translation He comes out prominently both as a grammatical and logical subject. In the second couplet in Indonesian, the grammatical subject is pintu and the logical subject is nya, and the di-Verb-nya is fronted to the beginning of the sentence, preceding the grammatical subject pintu. In contrast, He in the translation stands out both as the grammatical and logical subject. In the third couplet, the compound grammatical and logical subject (sepi and paduan dua jiwa) is preceded by the predicate hancur luluh. In the translation, the compound subject is fronted and becomes more prominent. Briefly, in English, subject stands prominent: it shows up explicitly in the sentence and takes a prominent position in terms of word order.

To recapitulate, different structures across languages manifest themselves in unequal grammaticization and syntactic patterning. Both of these structural aspects may probably be considered as truly languagespecific phenomena, and they are apparently independent of culture-specific conditioning. If their origin is at all explicable, it must be traced through the historical development of the individual language. The pedagogical implication of unequal grammaticization and syntactic patterning is that Indonesian learners of English need to keep on practicing "thinking in English" while learning this foreign language.

\section{Cultural Relativity and Language-Specific Expressions.}

In discussing the relationship between language and culture, most scholars in TEFL would agree with the widely accepted view that language exists in culture and that cultural values express themselves, among other things, by means of language. It is this view that relates cultural relativity with linguistic relativity. At the theoretical level, the recent re-emergence of linguistic relativity can be seen as a reaction against excessive formalism in linguistic universality, particularly as advocated by the Chomskyan school (see, e.g., Becker 1995 and Duranti 1997). When it goes too far, formalism no longer serves as a device for linguistic analysis; but rather it gives students of language a strong impression: formalism for the sake of formalism. At the analytical level, culture-specific items or values may be expressed at the word level or alternatively at the discourse level. For the former, I propose the term "culture-specific lexicalization," and for the latter "culturally conditioned verbalization."

\section{Culture-Specific Lexicalization}

Whereas "to gammaticize" means to put a concept into a grammatical marker, "to lexicalize" means to put a concept into words. When lexicalization occurs in one particular culture but not in another, we obtain "culture-specific lexicalization." To illustrate, let's take the word "rice" in English, which may occur as the same word in sentences (13).

(13) a. The farmers plant rice.

b. After the harvest, they dry the rice.

c. We buy rice at the supermarket.

d. He had rice and fish for breakfast.

I contrast, the concept contained in the word "rice" in each of the English sentences above is given a different lexicalization in Indonesian.

(14) a. Para petani menanam padi di sawah.

b. Setelah panen, mereka mengeringkan gabah.

c. Kita membeli beras di pasar swalayan,

d. Dia makan nasi dan ikan untuk sarapan.

Why does English have only one word (i.e., rice) as an equivalent of four different words (i.e., padi, gabah, beras, nasi) in Indonesian? This is probably because the object is socio-psychologically distant in English 
culture but intimate in Indonesian culture. That is, rice grows in the tropic, and in Indonesia it serves as staple food. The old linguistic tale that the Eskimo have numerous words for different types of 'snow' and the Arabs have numerous words for different types of 'sand' is also explicable in terms of socio-psychological intimacy.

In comparison, English-speaking people mostly belong to advanced industrial society. So the Indonesian noun cara has five equivalents in English: "way," "manner," "method," "mechanism," and "technique"-the last three being part of scientific jargon. The present-day Indonesian words metode, mekanisme, and teknik indicate that, if we want to keep the meanings of the English words intact, we can do nothing but "borrow" those words from English. Similarly, the verb meramal in Indonesian may be translated into "foretell," "predict," or "forecast"- the last two reflecting progress in science and technology. All of the examples given to this point show that the way people perceive the world is in part determined by the culture they live in.

Different ways of lexicalization may also pertain to a cultural value such as politeness. It is true that "politeness" is a universal cultural concept which exists in every culture. However, in verbal communication across languages politeness may be lexicalized differently. Take the second pronominal as an example. In Modern English it is lexicalized as "you." In contrast, the Indonesian pronominal may range from kamu, engkau, Anda, to the second pronoun substitutes such as Saudara, Bapak/Ibu (+ proper name), Abang/Kakak or Bang/Kak (+ proper name), up to the zero pronoun. In actual verbal communication, a speaker of Indonesian has to choose one among the available second pronominals or its substitutes as required by the politeness rules governing language use. These politeness rules are determined by sociocultural factors such as age, gender, social status, educational/economic/religious background, and distance or intimacy (Hudson 1980: 13). Consider the following short message service (sms) sent to me by an S2 student at the PPS UM.

(15) Excuse me, Sir. Can I see Pak Effendi today?

When read out of context, the terms of address "Sir" and "Pak Effendi" in sentence (15) would refer to two different persons-which is of course not the meaning intended by the student who wants to see me. Obviously, this is an example of sociopragmatic transfer; and the sentence is a direct translation of the Indonesian sentence in (16),
(16) Maaf, Pak. Dapatkah saya menemui Pak Effendi hari ini?

In this sentence the pronominal substitute Pak Effendi could not be replaced by kamu or even Anda, without causing some offense to the addressee.

To summarize, different ways of lexicalization may be due (a) to relative socio-psychological distance toward a particular object, or (b) to politeness penetrating part of the lexis. In the lexical paradigm, as shown in Figure 1, the former is best represented as horizontal sub-divisions and the latter as vertical sub-divisions. Both (a) and (b) may be termed as "unequal lexicalization." Errors in lexical choice made by $L 2$ learners related to (a) would result in "queer expressions," such as *menanam beras (instead of menanam padi) or *weather prediction (instead of weather forecast). On the contrary, errors related to (b) would cause offense to the addressee. In my own personal experience, when I was addressed as kamu by an American student learning Indonesian as in (17)

(17) Sudah lama kamu di Hawaii?

I was shocked and felt offended. But then the offense subsided as soon as I realized that he was an L2 learner of Indonesian at the elementary level, and by then he had not acquired the rules of politeness governing the use of second pronominals in Indonesian.

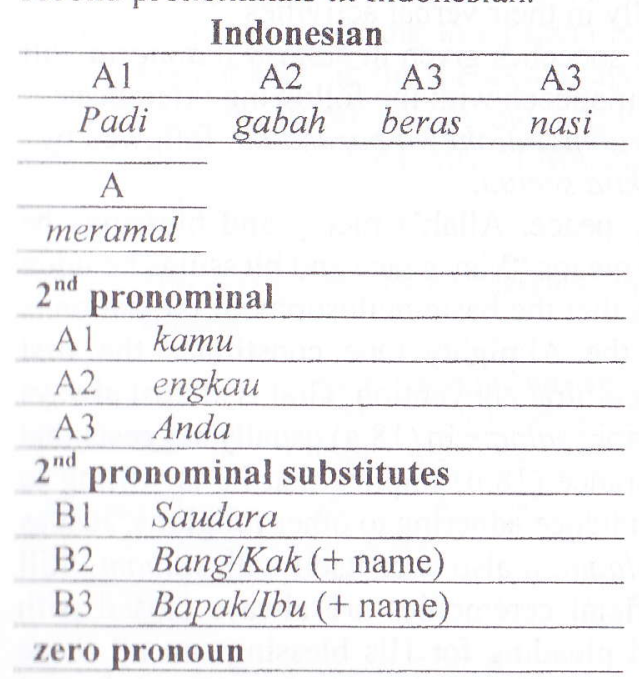

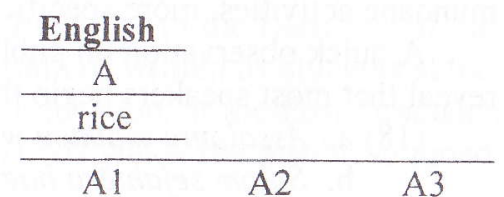

\begin{tabular}{|c|c|c|}
\hline Al & A2 & A3 \\
\hline foretell & forecast & predict \\
\hline \multicolumn{3}{|c|}{ 2nd pronominal } \\
\hline you & & \\
\hline
\end{tabular}

Figure 1. Examples of Unequal Cross-Linguistic Lexicalization 
It should be kept in mind that illustrative examples presented and discussed in this section constitute only part of unequal lexicalization, and hence part of the common problems in the lexical area for L2 learners. Other issues related to unequal lexicalization in Indonesian and English may include collocation and idiomaticity. However, since the major concern of this section is culture-specific lexicalization, other lexical issues not directly related to cultural relativity are set aside, so that the present paper may stay focused on the topic under investigation.

\section{Culturally Conditioned Verbalization}

Just as "politeness" is a universal cultural notion, so are the "belief in God" and "apology." This section selects these two cultural concepts and presents them in order. Humans are religious beings in the sense that most of them cannot help believing in metaphysics or the supernatural. The belief in God or Gods and Goddesses as Supreme Beings is common across cultures. Here I will not talk about how different religions formally express this common belief by way of different doctrines. But I will point out how different cultures evoke their beliefs in God as seen in people's daily, mundane activities, more specifically in their verbal activities.

A quick observation on public speeches given in bahasa Indonesia will reveal that most speakers begin their speech with the following utterances:

(18) a. Assalamu alaikum warahmatullahi wa barakatuh, followed by b. Salam sejahtera bagi kita semua.

Utterance (18.a) means "May peace, Allah's mercy and blessings be upon you all," and utterance (18.b) means "May peace and blessings be upon you all." Both utterances remind us that the basic philosophy of the nation is Pancasila, where belief in God the Almighty One constitutes the first principle. Therefore, as part of the cultural convention ' God is almost always there' in the public speech. The Arabic salaam in (18.a) usually suggests that the speaker is a Moslem, and utterance (18.b) implies that he is willing to share the beliefs of people in the audience adhering to other religions. Just as the public speech opens up with salaam, it also ends itself with salaam. Still in connection with Pancasila, official ceremonies are always closed with doa, prayers to the Almighty God pleading for His blessings on all those present and the state of affairs at hand. Thus salaam in formal or informal public speeches and doa as a 'closing statement' in official ceremonies are examples of how the belief in God is verbalized in public life. Speakers of English learning Indonesian should be familiar with this religious verbalization, which has no equivalent in English culture.

In Indonesian sociocultural life, the 'divine presence' has become so deeply rooted in orality that any public speech, both formal and informal, usually begins with "Praise be to the Lord ..." In Indonesian colleges and universities, for example, a formal speech by the rector on the commencement or graduation day always begins with "Praise be to the Lord ..." In fact, every booklet of pidato pengukuhan gurubesar (inaugural address for professorship) also begins with "Praise be to the Lord ..." In this context, it is interesting to note how the 'divine presence' jumps-borrowing the terms introduced by Walter Ong (1982)-from orality to literacy. The professorship inaugural address lies in between orality and literacy, because it is an academic discourse (and hence part of literacy); but it is to be delivered as a formal, ceremonial speech (and hence part of orality).

Moving farther and deeper into the domain of literacy, it is interesting to note that the 'divine presence' or "Praise be to the Lord ..." also goes ineluctably into the magister theses and doctoral dissertations, in spite of the fact that they are full-fledged scholarly works. A small library research (conducted prior to writing this paper) on "Praise be to the Lord ..." in the "Acknowledgments" in the theses and dissertations written by students at the Study Programs of Indonesian and English Education, at the Post-Graduate School (PPS), State University of Malang (UM) yields the results summed up in Table 2.

Table 2. Percentages of 'Divine Presence' in Scholarly Works by Post-Graduate Students

\begin{tabular}{|c|c|c|c|c|c|c|c|c|c|c|}
\hline \multirow{3}{*}{$\begin{array}{c}\text { Type of } \\
\text { Scholarly Work }\end{array}$} & \multicolumn{5}{|c|}{ Written in Indonesian } & \multicolumn{5}{|c|}{ Written in English } \\
\hline & \multirow{2}{*}{$\begin{array}{l}\text { No. of } \\
\text { Copies }\end{array}$} & \multicolumn{4}{|c|}{ 'Divine Presence' } & \multirow{2}{*}{$\begin{array}{l}\text { No. of } \\
\text { Copies }\end{array}$} & \multicolumn{4}{|c|}{ 'Divine Presence' } \\
\hline & & yes & $\%$ & no & $\%$ & & yes & $\%$ & no & $\%$ \\
\hline Magister Thesis & 10 & 10 & 100 & 0 & 0 & 15 & 12 & 80 & 3 & 20 \\
\hline $\begin{array}{c}\text { Doctoral } \\
\text { Dissertations }\end{array}$ & 10 & 10 & 100 & 0 & 0 & 15 & 4 & 26.7 & 11 & 73.3 \\
\hline
\end{tabular}


Before collecting the data, I had three assumptions in mind. First, the 'divine presence' or "Praise be to the Lord ..." may probably be there in the "Acknowledgment" in the theses and dissertations written by students at the Study Program of Indonesian Education, since commonly it is part of the Indonesian cultural conventions. Second, the 'divine presence' may possibly be there in the "Acknowledgment" in the magister theses written by students at the Study Program of English Education - as a form of cultural transfer, since they still lack sensitivity to conventions in English culture. (That is, the 'divine presence' is never to be found there interfering the secular nature of scholarly works.) Third, the 'divine presence' may probably not be there in the "Acknowledgment" in the doctoral dissertations written by students at the Study Program of English Education, since they have supposedly become sensitive enough to conventions in English culture.

As for data collection, the magister theses - written both in Indonesian and English-were picked up from the rows at random by 5, starting from the latest theses available in the PPS UM library. Thus among the last 50 theses written in Indonesian and the last 75 theses written in English, the researcher picked up theses placed nos. $5,10,15, \ldots$ etc. Then he checked whether or not "Praise be to the Lord ..." is there in each "Acknowledgment"

However, while planning to do the same data-collection technique for "Acknowledgments" in the dissertations, they were not placed in rows but scattered in different shelves. So, the researcher decided to pick up any 10 among the latest dissertations written in Indonesian, and any 15 among the latest dissertations written in English. The limitation of 10 theses and 10 dissertations written in Indonesian is related to the first assumption above, and the expansion to 15 theses and 15 dissertations written in English is related to the second and third assumptions respectively.

As shown in Table 2, the first assumption proves to be $100 \%$ true. That is, all acknowledgments in the theses and dissertations written by students at the Study Program of Indonesian Education begin with "Praise be to the Lord ...," of course with different ways of wording. The second assumption is $80 \%$ true. That is, among 15 acknowledgments in the theses written by students at the Study Program of English Education, 12 or $80 \%$ of them begin with "Praise be to the Lord ..." Finally, the third assumption turns out to be $73.3 \%$ true. That is, among 15 acknowledgments in the dissertations written by students at the Study Program of English Education, 11 or $73.3 \%$ of them do not include "Praise be to the Lord ..."; only 4 or $26.7 \%$ of them do.

To illustrate how the 'divine presence' comes down to interfere with scholarly works, below are one quotation from a thesis and two quotations from dissertations written in English.

(19) "First of all, I realize that this thesis would not have been completed without the blessing of God. I am so grateful to Jesus Christ, my God and my Savior, for His blessings and guidance that enabled me to finish writing this thesis" (Manoppo, 2004: iii).

(20) "Alhamdulillahi rabbil 'alamiin. All praises and gratitude be to Allah, Lord of the 'Alamiin. It is entirely because of Allah that I was able to finish writing this dissertation draft entitled "..." On this occasion, I would like to express my gratitude to a number of people who, because of Allah, have helped me, directly as well as indirectly, go through my study in the doctoral program of the English Education Department, PPS UM" (Raja, 2003: xvii).

(21) "What has been existed $[s i c]$ in this dissertation is with the permission of the Lord of Universe. It is therefore to Allah SWT whom I, first of all, have to express my Thanks. Secondly, love and my prayers are hopefully expressed to our beloved Muhammad SAW, his family and companions" (Susilo 2004: 10).

The three quotations above, as noted earlier, are examples of cultural interference. While writing in English, the writers bring along with them part of the Indonesian cultural conventions. Moreover, quotation (19) tells us that the writer is a Christian; and quotations (20) and (21) tell us that the writers are Moslems. In fact, quotations (20) and (21) clearly indicate carrying over an aspect of orality into literacy. In social gatherings among the Moslems in Indonesia, it is very common for a speaker to begin his speech with puji svukur ('praise be to the Lord') and shalawat dan salam ('blessings be upon the Prophet Muhammad')-which are obviously transferred in quotation (21). In quotation (20), the puji syukur is made very explicit through direct citation of the Arabic wording, Alhamdulillahi rabbil 'alamiin ('Praise be to Allah, the Lord of the Worlds.)

Anecdotal accounts will shed more light on this issue of cultural transfer. In the second semester of the 2002-03 academic year, I taught ethnolinguistics. Two foreign students, one from Germany and the other from Holland, sat in for the course. When we came to the topic "religion and 
academic discourse," I brought in a research report in Indonesian. The preface begins with "Puji syukur kami panjatkan kepada Allah SWT ..." When I translated this into "Praise be to Allah, the Almighty Lord ..." and asked for their comments, both of them said, "It sounds very strange" in this context. "What if it were in German or in Dutch?" I asked further. They said, "It would be equally strange."

Closely related to the supernatural vs. worldly affairs are cross-cultural differences with regard to the belief in predestination in Indonesian culture vs. reference to earthly facts in English culture. The following data are from a colleague at the English Department, State University of Malang. Upon asking students at the S1 and S2 programs a question about their marital status, she occasionally obtains an 'interesting' answer as follows:

\section{(22) Instructor : Are you married?} Student : Not yet.

Similarly, her question about having children, directed to married students, also obtains the same 'interesting' answer.

(23) Instructor : Do you have children? Student : Not yet.

In Indonesian culture, getting married and having children are taken both as earthly facts and divine providence. So, saying "No" as a response to the question in (22) and (23) sounds like standing in the way against the upcoming but unknown destiny: who knows, God will make me meet my 'soul mate' soon; who knows, God will give us a child soon. By comparison, in English culture, getting married and having children are simply worldly facts. Thus, the equivalent conventional answer to the question in (22) is "No, I'm single," and to the question in (23) is "No," or "No, we're still trying," if the couple really want to have children. Notice that the Indonesian equivalent of "No, we're still trying" is "Belum, Tuhan belum memberi" (No, God has not given [us a child] yet). In brief, the Indonesian answer "Not yet" is a reflection of people's belief in the divine intervention with human affairs, whereas the English answer "No" is simply a reference to a worldly fact.

To sum up, sacred and mundane affairs are closely interrelated in Indonesian culture, but they are clearly separated in Western culture. Moving ahead, let's talk about "apology." Apology is another universal notion, since in every culture someone who has made a grave error is obliged to apologize. In the Indonesian context, however, apology takes place in wider social domains than it does in the Western context. Ending a speech, one would be likely to say,

(24) Kurang-lebihnya saya mohon maaf... into

Just like giving thanks, sentence (24) is of course translatable verbally

(25) Should there be any mistakes, I apologize ...

But, the convention in English never allows an apology to end a public speech, and hence it is rejected culturally. For the same reason, the well known saying in a lebaran card:

(26) Selamat Idul Fitri. Mohon Maaf Lahir dan Batin

is only partly translatable, and hence

\section{(27) Happy Eid.}

The apology part is culturally untranslatable, although verbally it is.

(28) * My apology for the outer errors and inner sins.

Even in the Arab countries, from which Islam originated, people say to each other Eid Mubarak (Happy Eid) only, even though, linguistically speaking, Mohon Maaf Lahir dan Batin may well be translated into

(29) 'A fwan min fadhlikum dha: hiran wa ba:thinan.

While this saying in Arabic sounds idiomatic enough, the Arabs do not say so-because it is not part of their cultural convention.

To end this discussion on apology, the following quotation from Errington (1985) is of special interest. In his book Language and Social Change in Java, he ends the preface with the following paragraph.

(30) To the many others to whom I am obliged, but cannot name here, and to those who do not wish to be named here, my thanks. Manawi wonten kalepatan salebeting karangan punika, kula nyuwun pangapunten.

Verbally, the Javanese sentence would be translatable into

(31) * Should there be any mistakes in this book, I apologize (to the reader).

Why does Errington end his preface with an apology in Javanese? Because it is both culturally and linguistically permissible. Should the Javanese sentence in (30) be replaced by the English sentence in (31), Western readers would be horrified. In ending the preface in a Javanese way, Errington has been successful in placing a Javanese cultural value within the context of Western academic convention. In addition, this seems to be one best way of how a researcher in anthropological linguistics should appreciate 
his research subjects. Errington's work is thus a fine example in which cultural conventions of West and East can meet.

As an addendum to this section, I would like to present Indonesian and English wedding invitations (Figures 2a., 2.b, and 3). Figure 2.b is a literal English translation for the wedding invitation in Indonesian, provided for readers unfamiliar with the Indonesian language. A quick look at figures 2.a and 3 will reveal the following. First, the wedding invitation in Indonesian sounds strongly religious, notably Islamic, as shown by the phrases Bismillaahirrahmaanirrahiem (In the name of Allah, Most Gracious, Most Merciful), Dengan memohon rahmat serta ridha Allah SWT (By the grace and blessing of Allah the Almighty) and insya Allah (if Allah wills-this is deleted in the literal translation). In contrast, the wedding invitation in English shows very little religiosity, if at all, namely by the mention of Cibunul Church as the venue. Secondly, in the Indonesian wedding invitation, the hosts, together with the bridal couple, come down late at the bottom; but in the English wedding invitation the hosts stand out prominently at the top. At this point, the reader may recall the rule of subject prominence in English, but not in Indonesian (discussed earlier in section II.A, Linguistic Relativity and Thought Patterns.) Shortened into sentential paraphrases, the Indonesian wedding invitation would read "You are invited to the wedding reception by us," but the English wedding invitation would read "We invite you to the wedding reception." In other words, both wedding invitations are, linguistically speaking, discoursal projections of sentential structures in both languages. In this regard, passive as a means of showing politeness looks obvious in Indonesian culture, whereas active as a means of showing responsibility looks obvious in English culture. To push further, the subject is often literally and metaphorically suppressed in a collectivistic society; but it is required to stand out prominently in an individualistic society. Taking the first person singular as a contrastive example is of particular interest: saya in Indonesian was derived from Old Malay sahaya, meaning 'slave,' whereas I in English is much like a 'king., for its unfailing dominant presence - regardless of its syntactic position—via the capital letter "I."
Bismillaahirrahmaanirrahiem

Dengan memohon rahmat serta ridha Allah SWT kami bermaksud menyelenggarakan syukuran pernikahan putra-putri kami.

yang insya Allah akan diselenggarakan pada:

Hari Minggu, 21 September 2003

Pukul 11.00 - 14.00 WIB

Bertempat di Jl. Danau Singkarak G7F No. 23

Sawojajar, Malang

Merupakan suatu kehormatan dan kebahagiaan tersendiri

bagi kami apabila Bapak/Ibu/Saudara/i

berkenan hadir untuk memberikan do'a restu kepada kedua mempelai.
Keluarga
Edy Suhardi
Keluarga
dr. P. Y. Suryoprabowo

Vita \& Yohan

Figure 2.a. Wedding Invitation in Indonesian

In the name of Allah, Most Gracious, Most Merciful

By the grace and blessing of Allah the Almighty, we intend to have a wedding reception for our children on:

Monday, 21st of September 2003

at 11.00 a.m. -14.00 p.m.

on Jl. Danau Singkarak G7F No. 23

Sawojajar, Malang

It would be an honor and happiness for us

if you would be willing

to be present and give blessings on the bridal couple.

$$
\begin{array}{cc}
\text { Family of } & \text { Family of } \\
\text { Edy Suhardi } & d r . \text { P. Y. Suryoprabowo }
\end{array}
$$

Vita \& Yohan

Figure 2.b. Literal English Translation of the Indonesian Wedding Invitation 
Mrs. Melinova Sapoetra \& Mr. Soemardi Sapoetra together with

Mrs. Donna Rolins \& Mr. George Rollins

Request the honor of your presence at the marriage of their children

$$
\text { Lydia Sapoetra }
$$

Trevor Rollins

On Wednesday the sixth of October

two thousand and four

nine thirty in the morning

at Cibunul Church

Van de Venter Eleventh

Bandung Indonesia

\section{Figure 3. Wedding Invitation in English}

To summarize, in Indonesian culture humans cannot stay away from the divine, and apologetic as well as passive attitudes are encouraged so as to preserve the spirit of collectivism. In contrast, in English culture human affairs are mostly secular, and assertive attitudes as well as active participation are encouraged so as to keep reviving the elan vital of individualism. Thus learning the English language means also learning English culture, for bilingualism by definition includes biculturalism, albeit largely but never totally.

\section{CONCLUSION: TEFL-LINGUISTICS ACROSS CULTURES}

"There is nothing new under the sun," and I believe it. In fact, I practice it: this paper is my plagiarism in its best. The first part of the paper is a direct quotation from Sapir (1921), the second part a modification of Chaika (1982), and the last part a verbatim citation of Lado (1957). The gist of the matter is this: the same object viewed from different perspectives may give a novel picture, a new significance, and an added value. Linguistic relativity was once defined by Martin Joos (1957: 96) as follows: "languages could differ from each other without limit and in unpredictable ways." He pushed the principle of relativity too far, making linguistics lose its generality. Then Chomsky (1965) came to the stage and revived the old idea of universal grammar. But as the generative enterprise has lately become more and more theory-driven, his principle of universality is carried away by excessive formalism, making human language lose its lively human nature. So the recent re-emergence of linguistic relativity is in part driven by extreme formalism in linguistic theory which gives too much emphasis on universality.

"The middle way is golden," and I believe it. In my opinion, universality and relativity in linguistics are much like the north and south poles; one could never exist without the presence of the other. According to the principle of universality, human languages are essentially the same; but according to the principle of relativity, every human language is unique, structurally as well as culturally. The two principles may sound contradictory, but they are not. The universal principle provides general parameters available in all languages; and the relative principle shows how each of these parameters varies across languages. At the phonemic level, for example, all languages have consonants and vowels. However, English has 22 consonants and 12 vowels, whereas Indonesian has 20 consonants and 6 vowels. At the morphemic level, complex words consist of free and bound morphemes or affixes. English has only prefixes and suffixes, but Indonesian has prefixes, suffixes, some infixes, and simulfixes. At the syntactic level, every structure of modification consists of head and modifier. Nevertheless, in English a one-word modifier usually precedes the head while in Indonesian the head commonly precedes the modifier. All these examples clearly underline the surviving validity of contrastive analysis outlined by Fries (1945) and Lado (1964).

But Lado moves further: Linguistics across Cultures. All the topics presented and discussed in part II of this paper go back to the old notions hidden in Lado's 1957 proposal: linguistic relativity and cultural relativity. Or, if you wish, they may go back to the much older Saussurean ideas: the arbitrary nature of signified and signifier, or concept and sound image, or more familiarly meaning and form. The concepts such as "time" and "space" are there in the collective mind of English and Indonesian speakers; but only in English these concepts are grammaticized. Politeness in verbal communication is a universal concept, but how it is lexicalized may differ from one language to another, as shown by different forms of the second 
pronominal in English and Indonesian. Thus grammaticization and lexicalization themselves are universal processes of putting meaning into form. But if these processes yield different forms across languages, they constitute parts of linguistic relativity.

Moving deeper into the culture, religiosity is no doubt a cultural universal. But the sociocultural context in which the divine is explicitly verbalized may differ from one culture to another. When "Praise be to the Lord ..." goes into a scholarly work in English, there is nothing wrong linguistically; but it sounds very strange culturally. This is an example of negative cultural transfer. Similarly, apology is a universal cultural concept. But, much like religiosity, its verbalization is culturally determined. If it is verbalized beyond the confines of cultural conventions, it may also result in negative transfer. Since the domains for religiosity and apology in Indonesian culture are wider than those in English culture, negative transfer is expected to occur in Indonesian learners' spoken or written English. At this point, it is obvious that I am repeating Lado's Contrastive Analysis Hypothesis, now projected into wider areas of macro-linguistics.

For the purpose of enhancing TEFL in Indonesia, I agree with the advocates who state that there is no best method for TEFL. Therefore, following Hammerly (1982: 24-5), I suggest picking up eclecticism, or more accurately enlightened eclecticism, in TEFL. That is, picking up what is best from the theories and methods we are truly familiar with for the practical purpose of solving the teaching problems at hand. Learning from American Structuralism that "language is primarily speech," we give our students sufficient drilling to help them acquire good pronunciation. Learning from Generative Grammar that "language is fundamentally creative," and from Krashen's that "only comprehensible input may become intake," we help our students develop their L2 competence by exposing them as much as we can to comprehensible input used in a natural setting. Learning from Hymes (1972) about communicative competence, we train our students-by way of communicative approach-to produce utterances which are grammatically correct, pragmatically and sociolinguistically appropriate, and strategically effective. Moreover, sociolinguists tell us that "language is a mirror of the society," and anthropological linguists tell us that "language is a mirror of the culture." Incorporating both metaphors (i.e., language as a social and cultural mirror) into the CCU class, we help our students become truly aware of cross-cultural distinctions and fully realize the importance of acquiring cultural sensitivity in an EFL setting.

In conclusion, we EFL teachers aim to produce students who have an excellent command of English-fluent in speech, well-versed in grammar, at ease in communication, and feeling at home in the EFL cultural surroundings. A generation ago, when radio was a rarity and TV was a luxury, talking about CCU was much like building castles in the air. But today, as the information technology has become more accessible and the world is becoming smaller and smaller, crossing cultural barriers is no longer a big problem. Hence, our attempts to make the best use of linguistic and cultural relativity as a gateway toward bilingualism and biculturalism should move closer to reaching the heart of the foreign language culture.

\section{Acknowledgments}

I am particularly grateful to Dr. Arwiyati W. Murdibyono for proof-reading the final draft of this paper, giving valuable suggestions for its improvement, and providing more data on the subtopic of sacred vs. mundane affairs. Should there be any shortcomings remaining, however, I alone am responsible for them. My sincere thanks also go to Aulia Apriana, S. S. for helping me do the library research on "Praise be to the Lord ..." in the acknowledgments within the magister theses and doctoral dissertations at the PPS UM, to Dra. Sri Andreani, M.Ed. for helping me find a wedding invitation in English, and to Dr. Nurul Murtadlo, Chair of the Arabic Department, UM, for cross-checking the acceptability of the made-up apology in Arabic.

\section{REFERENCES}

Becker, Alton L. 1995. Beyond Translation: Essays toward a Modern Philology. Ann Arbor: The University of Michigan Press.

Chaika, Elaine. 1982. Language the Social Mirror. London: Newbury House Publishers, Inc.

Chomsky, Noam. 1965. Aspects of the Theory of Syntax. Cambridge, Massachusetts: The MIT Press.

Duranti, Alessandro. 1997. Linguistic Anthropology. Cambridge: Cambridge University Press.

Errington, J. Joseph. 1985. Language and Social Change in Java. Athens, 
Ohio: Ohio University Center for International Studies, Monographs in International Studies, Southeast Asian Series Number 65.

Fries, Charles C. 1945. Teaching and Learning English as a Foreign Language. Ann Arbor: The University of Michigan Press.

Hammerly, Hector. 1982. Synthesis in Language Teaching: An Introduction to Linguistics. Blaine, W.A., U.S.A.: Second Language Publication.

Hudson, R. A. 1980. Sociolinguistics. Cambridge: Cambridge University Press.

Hymes, Dell. 1972. Competence and Performance in Linguistic Theory. In Huxley, R. \& Ingram, B. (eds.). Language Acquisition: Models and Methods. London: Academic Press, pp 3-28.

Jakobson, Roman. 1959. Boas' View of Grammatical Meaning. American Anthropologist, 61: 139-45.

Joos, Martin. 1957. Readings in Linguistics. New York: American Council of Learned Societies.

Krashen, Stephen D. 1982. Principles and Practice in Second Language Acquisition. New York: Prentice-Hall International.

Lado, Robert. 1957. Linguistics across Cultures. Ann Arbor: The University of Michigan Press.

Lado, Robert. 1964. Language Teaching: A Scientific Approach. New York: McGraw-Hill, Inc.

Lavandera, Beatriz R. 1988. The Study of Language in its Sociocultural Context. In Newmeyer, Frederick J. (ed.). Linguistics: The Cambridge survey, vol. IV: Language: The socio-cultural context, pp. 1-13. Cambridge: Cambridge University Press.

Manoppo, Anita Luisa. 2004. Using Language Games to Improve the Speaking Ability of the Second-year Students at SMP Negeri 5 Manado. P.P.S. Universitas Negeri Malang: Unpublished Thesis.

Ong, Walter J. 1982. Orality and literacy: the technologizing of the word. London, New York: Routledge.

Raffel, Burton. 1993. The Voive of the Night: Complete Poetry and Prose of Chairil Anwar. Athens, Ohio: Monographs in International Studies, Southeast Asia Series Number 89.

Raja, Patuan. 2003. The Language of an Indonesian Child Named Mika in the Telegraphic and Simple Sentence Stage. P.P.S. Universitas Negeri Malang: Unpublished Dissertation.
Rivers, Wilga M. 1981. Teaching Foreign-Language Skills (Second Edition). Chicago and London: The University of Chicago Press.

Sapir, Edward. 1921. Language: An Introduction to the Study of Speech. San Diego, New York, London: Harcourt Brace Jovanovich, Publishers.

Saussure, Ferdinand de. 1959. Course in General Linguistics (English translation by Baskin, W.). New York, Toronto, London: McGraw-Hill Book Company.

Slobin, Dan I. 1996. From "Thought and Language" to "Thinking and Speaking." In Gumperz, John J. \& Levinson, Stephen C. Rethinking Linguistic Relativity, pp. 70-96. Cambridge University Press

Smith, Neil. 1999. Chomsky: Ideas and ldeals. Cambridge: Cambridge University Press.

Susilo. 2004. Thought Patterns as Reflected in the Linguistic Features in Indonesian and English Letters Written by Indonesians. P.P.S. Universitas Negeri Malang: Unpublished Dissertation.

White, Lydia. 1989. Universal Grammar and Second Language Acquisition. Amsterdam/Philadelphia: John Benjamin Publishing Company. 